\title{
Penerapan Metode TOPSIS Dalam Penentu Beasiswa Pada Siswa SMK TR SINAR HUSNI
}

\author{
Application of the TOPSIS method in determining scholarships for students of SMK TR \\ SINAR HUSNI
}

\author{
Adil Setiawan ${ }^{1}$, Hardianto ${ }^{2}$, Fhery Agustin ${ }^{3}$ \\ Program Studi Rekayasa Perangkat Lunak ${ }^{1}$ \\ Program Studi Informatika ${ }^{2,3}$
}

Fakultas Teknik dan Ilmu Komputer, Universitas Potensi Utama

E-mail : adio165@gmail.com, hardianto2008@yahoo.co.id, fhery_agustin@yahoo.co.id

\begin{abstract}
Abstrak
Program PenentuBeasiswa merupakan program kerja sama yang dilakukan oleh setiap Lembaga Pendidikan baik di sekolah ataupun pada perguruan tinggi. Dalam hal ini termasuk bahwa setiap beasiswa dilakukan untuk mengurangkan biaya siswa untuk menempuh pendidikan khususnya yang terkendala dalam biaya. Calon penerima dipilih sesuai dengan ketetapan yang sudah ditentukan oleh pihak sekolah. Sesuai dengan aturan atau ketetapan yang sudah ditentukan tersebut maka pihak sekolah dapat memilih siapa saja yang akan dipilih untuk mendapatkan beasiswa. Guna membantu menentukan dan menetapkan seseorang yang layak mendapatkan beasiswa maka dibutuhkan sebuah sistem pendukung keputusan yaitu dengan menggunakan metode Technique Order Preference by Similarity To Ideal Solution (TOPSIS). Metode ini digunakan karena dapat memilih alternative terunggul, alternative yang ditargetkan yakni yang boleh mendapatkan penyaluran beasiswa berdasarkan kriteria yang telah ditentukan. Riset ini dibuat demi menentukan nilai bobot untuk setiap atribut, lalu dilakukan proses pengurutan I perangkingan kandidat yang dapat menentukan alternative yang optimal, dengan menggunakan metode tersebut diharapkan hasil penilaian lebih tepat karena ditentukan pada nilai kriteria dan bobot yang telah ditentukan sehingga mendapatkan hasil yang lebih akurat bagi orang yang akan mendapatkan beasiswa itu.
\end{abstract}

Kata Kunci-Beasiswa, Sekolah, TOPSIS.

\begin{abstract}
Scholarship Distribution Program is a collaborative program carried out by every Educational Institution both in schools and in universities. In this case, including that every scholarship is carried out to reduce the cost of students to study especially those that are constrained by fees. Prospective recipients are selected in accordance with the provisions that have been determined by the school. In accordance with the rules or regulations that have been determined, the school can choose anyone who will be selected to get a scholarship. To help determine and determine someone who deserves a scholarship, a decision support system is needed, namely by using the Technique Order Preference by Similarity To Ideal Solution (TOPSIS) method. This method is used because it can choose the best alternative, the targeted alternative that is allowed to get scholarship distribution based on predetermined criteria. This research was made to determine the weight value for each attribute, then the candidate ranking / ranking process was carried out that could determine the optimal alternative, using the method expected to be more precise assessment results because it was determined on the criteria and weight values that have been determined so as to get more accurate results for people who will get the scholarship..
\end{abstract}

Keywords —Scholarship, School, TOPSIS. 


\section{PENDAHULUAN}

Penyaluran beasiswa merupakan suatu bantuankeuangan yang ada di setiap lembaga pendidikan. Beasiswa merupakan bantuan keuangan yang bertujuan untuk membatu meringankan siswa dalam hal biaya dan juga untuk mendukung pendidikan bangsa. Beasiswa merupakan suatu bantuan berupa keuangan yang bertujuan untuk membatu meringankan siswa-siswi dalam biaya dan untuk mendukung pendidikan bangsa.Beasiswa tidak berasal dari sumber dana sendiri atau orang tua siswa, melainkan berasal dari negara (pemerintah), wiraswasta (pelaku usaha swasta), universitas, serta yayasan (lembaga pendidik) atau peneliti, juga dari kantor bekerja yang memiliki karyawan berprestasi sehingga diberikan kesempatan untuk menambah wawasan melalui pendidikan yang disedikan. Pada saat ini sangat banyak beasiswa yang diajukan kepada para siswasiswi yang kurang mampu serta berprestasi agar siswa mendapat keringanan dalam melaksanakan pendidikan khususnya untuk masalah biaya. Untuk mengantisipasi agar beasiswa tersalurkan kepada yang berhak maka penerima beasiswa harus dipilih berdasarkan kriteria yang telah ditentukan. Pengelola Lembaga saat ini masih menentukan cara penentuan siswa-siswi baru yang berhak mendapatkan beasiswa. Sedangkan Pada sistem pengolah data masih kurang efektif, sehingga sangat membutuhkan waktu yang sangat relative lama dan sering memunculkan terjadinya subjektivitas dalam pengambilan keputusan. Adanya hal tersebut dikhawatirkan menimbulkan kerancuan dan ketidaktepatan penilaian sehingga membuat tidak tepat sasaran beasiswa yang ingin disampaikan kepada orang yang berhak. Dengan Permasalahan diatas dapat di selesaikan dengan membangun suatu Sistem Penunjang Keputusan (SPK) dengan penerapan metode perangkingan.

Dengan membangun sistem akan mempermudah para pengambil keputusan dan pengurus sekolah dalam memilih siswa-siswi baru yang berhak mendapatkan beasiswa, maka diperlukan suatu system rekomendasi yang berfungsi membantu melancarkan seleksi kepada calon penerima beasiswa. System rekomendasi pemberian beasiswa adalah suatu system yang memiliki fungsi untuk membantu pengurus sekolah melakukan penyeleksian terhadap para calon penerima beasiswa. Oleh karena itu metode yang akan diterapkan dalam penelitian ini adalah Technique for Order Preference by Similarity to Ideal Solution (TOPSIS).

Metode ini dipilih karena mampu menyeleksi alternatif dari sejumlah alternatif. Penerapan metode TOPSIS sudah dilakukan beberapa peneliti, seperti Seleksi Penerimaan Calon Karyawan Menggunkan Metode Topsisyang mampu menyeleksi penerimaan guru dengan sangat baik dari Sri Lestari, [1] Penelitian dilakukan menggunakan proses perangkingan yang menetapkan alternatif yang optimal. Pemilihan dalam penerima beasiswa menggunakan metode TOPSIS kelebihannya yaitu proses menyeleksi menjadi lebih mudah dikarenakan merangking anggota terpilih berdasarkan susunan prioritas alternatif. Harapan Pada Sistem yang dibangun dapat membantu SMK TR SINAR HUSNI Helvetia Medan dalam membuat keputusan secara cepat, tepat, dan adil terhadap penerimaan beasiswa sekolah gratis.

Maksud dari sistem yang menggunakan SPK tidak untuk mengotomatiskan pengambilan keputusan, tetapi akan memberi perangkat interaktif dengan pilihan yang memudahkan pengambil keputusan untuk melakukan berbagai analisis dengan mempergunakan model yang tersedia. Dengan hasil dari penelitian yang sebelumya, Penelitian ini menggunakan metode TOPSIS (Technique for Order by Similarity to Ideal Solution) dengan pemilihan model juga simulasi akan seleksi penerima beasiswa bidikmisi berbasis web. Sehingga, Metode TOPSIS membutuhkan kriteria yang terdapat bobot didalamnya untuk melakukan perhitungan sehingga akan mendapat alternatif terbaik. Pada Penelitian ini Penggunaan kriteria dapat dihasilkan dari wawancara dengan penyeleksi penerimaan beasiswa (panitia) [2]

Pada SPK terdapat tujuan utama yang merupakan proses mengambil keputusan dengan baik dan seefektif mungkin. Dengan adanya penggunaan 8 variabel pada masing-masing dari variabel terdiri dari parameter-parameter yang berbeda, satu variabel keluaran hasilnya adalah ditolak atau diterima. [3][4]. 


\section{METODE PENELITIAN}

2.1. Beberapa rule Pembangunan sistem ini antara lain :

Membangun Sistem Pengambilan Keputusan, terdapat beberapa tahapan prototyping sebagai berikut:

1. Membangun Prototyping

Menyusun rancangan merupakan bagian sementara dengan fokus presentasi kepada pengguna.

2. Evaluasi Prototyping

Evaluasi dibuat bertujuan apakah prototyping telah dibangun sesuai dengan keinginan. Jika sudah selanjutnya langkah 4 akan diambil. Jika tidak prototyping akan dikoreksi dengan mengulangi langkah 1, 2, dan 3. [5]

3. Pengumpulan Kebutuhan

Hal penting dilakukan adalah merumuskan masalah dan menentukan tujuan membangun SPK. memastikan jenis SPK sesuai yang dirancang dan rulr pengerjaan metode yang dilaksanakan.

\subsection{Karakteristik Decision Support System (DSS)}

DSS ,empunyai beberapa tahapa karakteristik dasar denga kriteria berikut :

a. DSS lebih bersifat kontributif, bukan melahirkan hasil pendukung sistem.

b. DSS digunakan untuk mengurus transformasi atau perubahan kebutuhan dari pembuat keputusan denga cepat. Tipe DSS seperti sistem informasi lainnya, pada dasarnya terdiri tiga bagian utama yaitu masukan, proses,dan keluaran.

c. hal yang membedakan DSS dengan tipe sistem informasi lainnya adalah jenis-jenis input dan output serta proses yang dilakukan.

d. DSS didesine khusus dengan tujuan memudahkan proses pengambilan hasil sistem keputusan. [6][7].

Langkah - langkah untuk menyelesaikan permasalahan menggunakan metode TOPSIS: . [8][9]

1) Membuat matriks keputusan yang ternormalisasi.Metode TOPSIS membutuhkan rating kinerja setiap alternatif Ai pada setiap kriteria Ci yang ternormalisasi.

$r i j=\frac{x i j}{\sqrt{\sum_{i=1}^{m} x_{i j}^{2}}}$

- Dengan $\mathrm{i}=1,2, \ldots \ldots, \mathrm{m} ; \mathrm{dan} \mathrm{j}=1,2, \ldots, \mathrm{n}$.

- $\quad$ rij = matriks keputusan ternormalisasi.

- $\quad x i j=$ bobot kriteria ke $\mathrm{j}$ pada alternatif ke $\mathrm{i}$.

- $\mathrm{i}=$ alternatif ke $\mathrm{i}$.

- $\mathrm{j}=$ kriteria ke $\mathrm{j}$.

2) Membuat matriks keputusan yang ternormalisasi terbobot.

$\left[\begin{array}{lll}y 11 & y 21 & y i j \\ y 21 & y 22 & y i j \\ y 31 & y 32 & y i j\end{array}\right]$

Keterangan:

- $\quad \mathrm{Wj}$ adalah bobot kriteria ke-j

- Yij adalah elemen dari matriks keputusan yang ternormalisasi 
3) Menentukan matriks solusi ideal positif dan matriks solusi ideal negatif

$$
\begin{aligned}
& A^{+}=\left(\mathrm{y} 1^{+}, \quad \mathrm{y} 2^{+}, \quad \mathrm{yi}^{+}\right) \\
& A^{-}=\left(\mathrm{y} 1^{-}, \quad \mathrm{y}^{-}, \quad \mathrm{yi}^{-}\right)
\end{aligned}
$$

Dimana :

$j y^{+}=\max$ yij, jika $\mathrm{j}$ adalah atribut untuk min yij, jika $\mathrm{j}$ adalah atribut biaya

$j y=\min y i j$, jika $\mathrm{j}$ adalah atribut keuntungan max yij, jika $\mathrm{j}$ adalah atribut biaya

4) Menentukan jarak antara nilai setiap alternatif dengan matriks solusi ideal positif (D+) dan (D-) matriks solusi ideal negative

$$
\begin{aligned}
& D^{+}=\sqrt{\sum_{i=1}^{m}\left(y i^{2}-y i j^{+}\right)^{\wedge} 2} . . \\
& D^{-}=\sqrt{\sum_{i=1}^{m}\left(y i^{2}-y i j^{-}\right)^{\wedge} 2} .
\end{aligned}
$$

Keterangan:

- $j y^{+}$adalah elemen dari matriks solusi ideal positif

- $j y$ adalah elemen dari matriks solusi ideal negative

5) Menentukan nilai preferensi untuk setiap alternatif. Nilai preferensi merupakan kedekatan suatu alternatif terhadap solusi ideal

$\frac{D_{i}^{-}}{D_{i}^{-}+D_{i}^{+}}$

Dimana:

Nilai Vi yang lebih besar menunjukkan prioritas alternatif [10][11][12][13]

\section{HASIL DAN PEMBAHASAN}

Kemiskinan merupakan suatu kondisi sosial ekonomi dari warga masyarakat yang belum memiliki kemampuan dalam mencukupi berbagai kebutuhan pokok yang memadai kemanusiaan. Kemiskinan juga persoalan global dan sering disangkutkan sebagai kebutuhan, kesulitan, dan kekurangan dalam keadaan hidup seseorang. adanya hal itu membantu dalam proses menentukan dan menetapkan seseorang layak mendapatkan beasiswa sangat dibutuhkan sebuah SPK dengan menggunakan metode Technique Order Preference by Similarity To Ideal Solution (TOPSIS). Metode ini memerlukan kriteria dan bobot di proses perhitungannya sehingga didapat alternatif terbaik. yaitu :

Metodologi pembahasan ini adalah metode TOPSIS yang terdapat beberapa langkahnya

1. Mulailah Menentukan suatu matriks solusi ideal positif dan matriks solusi ideal negatif

2. Setelah itu Menentukan kembali jarak antara nilai setiap alternatif dengan hubungan matriks solusi ideal positif dan negatif

3. selanjutnya, Menentukan nilai preferensi pada setiap alternatif.

4. Membuatkan matriks keputusan ternormalisasi berbobot.

5. Membuat tambahan matriks keputusan yang ternormalisasi. 


\subsection{Data yang diperlukan dalam contoh perhitungan SPK dengan metode TOPSIS}

Untuk contoh perhitungan spk dengan studi kasus seleksi pemberian beasiswa yang menggunakan metode topsis, akan dipersiapkan beberapa data sebelum dimulainya proses perhitungan yaitu sebagai berikut:

\subsection{Data Alternatif}

Data alternatif bagian dari orang/objek yang dinilai. Data alternatif terdapat kode alteranatif dan sebutan alternatif, pada atribut yang lain dapat disesuaikan oleh studi kasus. Contohnya kalau penerimaan beasiswa alternatif adalah siswa, sebagai kode alternatif dapat diganti menjadi nim, atau dapat ditambahkan atribut lain misalnya, jenis kelamin, jurusan, dan lain-lain. Berikut contoh data alternatif:

Tabel 1. Tabel alternatif

\begin{tabular}{|c|l|}
\hline Nomor & \multicolumn{1}{|c|}{ ALTERNATIF } \\
\hline 01 & Alwi Sihab \\
\hline 02 & Fanny Irvansyah \\
\hline 03 & Ilman Riki Maulana \\
\hline 04 & Ihsan Prandika \\
\hline 05 & Ahmad Fauzan \\
\hline
\end{tabular}

\subsection{Data Kriteria}

Berdasarkan hasil wawancara di dapat 8 kriteria dalam seleksi penerimaan beasiswa bagi siswa, beberapa dari kriteria tersebut akan memiliki alternatif kriteria yang memiliki kualitas pada nilai dari alternatif dari setiap kriteria berdasarkan tingkat kepentingan antara alternatif dari tiap kriteria. Perbandingan nilai tingkat kepentingan antara alternatif dengan kriteria yang satu dengan alternatif dan kriteria yang lainya ditetapkan dengan nilai 1 sampai 5 yaitu sangat rendah $=1$, rendah $=2$, cukup $=3$, tinggi $=4$ dan sangat tinggi $=5$. Ditetapkan Semakin tinggi suatu nilai bobot dari alternatif suatu kriteria, maka semakin pula tingkat dari suatu kepentingan alternatif dengan kriteria tersebut, maka dapat kita menarik sebuah kesimpulan. Selanjutnya kriteria-kriteria dan alternatifalternatif kriteria tersebut akan di jadikan sebagai penentu penerima beasiswa yang baik. Terdapat pada tabel 2:

Tabel 2. Penjelasan Kriteria dan Sub Aspek Kritera

\begin{tabular}{|c|c|c|}
\hline $\mathrm{NO}$ & KRITERIA & BOBOT \\
\hline \multirow[t]{6}{*}{1} & $\begin{array}{l}\text { Jumlah Penghasilan Orang } \\
\text { Tua }\end{array}$ & \\
\hline & a. $<=700.000$ & 5 \\
\hline & b. $>=700.000$ & 4 \\
\hline & c. $>=1.200 .000$ & 3 \\
\hline & d. $>=1.700 .000$ & 2 \\
\hline & e. $\quad>=2.200 .000$ & 1 \\
\hline \multirow[t]{6}{*}{2} & $\begin{array}{l}\text { Jumlah Anggota Keluarga } \\
\text { Tanggungan Orang Tua }\end{array}$ & \\
\hline & a. Anggota Keluarga 1 & 1 \\
\hline & b. Anggota Keluarga 2 & 2 \\
\hline & c. Anggota Keluarga 3 & 3 \\
\hline & d. Anggota Keluarga 4 & 4 \\
\hline & e. Anggota Keluarga $>5$ & 5 \\
\hline 3 & Tempat Tinggal Orang Tua & \\
\hline
\end{tabular}




\begin{tabular}{|c|c|c|}
\hline & a. $\quad$ Tidak Memiliki & 5 \\
\hline & b. Menumpang & 4 \\
\hline & c. Sewa Bulanan & 3 \\
\hline & d. Sewa Tahunan & 2 \\
\hline & e. Rumah Sendiri & 1 \\
\hline 4 & Nilai Rata -Rata Semester & \\
\hline & a. $91-100$ & 5 \\
\hline & b. $86-90$ & 4 \\
\hline & c. $81-85$ & 3 \\
\hline & d. $75-80$ & 2 \\
\hline & e. $70-74$ & 1 \\
\hline 5 & Prestasi Non Akademis & \\
\hline & $\begin{array}{ll}\text { a. } & \text { Prestasi Tingkat } \\
\text { Internasional }\end{array}$ & 5 \\
\hline & $\begin{array}{ll}\text { b. } & \text { Prestasi } \\
& \text { Nasional }\end{array}$ & 4 \\
\hline & c. Prestasi Tingkat Provinsi & 3 \\
\hline & $\begin{array}{lll}\text { d. } & \text { Prestasi } \\
\text { Kabupaten } & \text { Tingkat } \\
\end{array}$ & 2 \\
\hline & e. Ketua Osis & 1 \\
\hline 6. & Memiliki Kartu KIP & 5 \\
\hline 7. & Memiliki Kartu PKH & 5 \\
\hline 8. & Memiliki Kartu KKS & 5 \\
\hline
\end{tabular}

Adapun bagian data dari kriteria dijadikan dasar penilaian alternatif. Kriteria dapat berupa cost atau benefit. Benefit semakin besar nilainya semakin bagus, sebaliknya cost semakin kecil nilainya semakin bagus. contoh, pada studi kasus penerima beasiswa, maka nilai iswa sebagai benefit, dikarena samakin besar siswa semakin peluang besar untuk terpilih. Sedangkan sebagai cost penghasilan orang tua, dikarena penghasilan orang tua besar tentu memperkecil peluang layak menerima hasil keputusan.

Berdasarkan kriteria didapatkan bobot kriteria berdasarkan tingkat kepentingan dari tiap-tiap kriteria tersebut $\mathrm{C} 01=5, \mathrm{C} 02=5, \mathrm{C} 03=1, \mathrm{C} 04=3, \mathrm{C} 05=4, \mathrm{C} 06=5, \mathrm{C} 07=5, \mathrm{C} 08=5$, maka pengambilan keputusan memberikan bobot preferensi $\mathrm{W}=(5,5,1,3,4,5,5,5)$. Total bobot kriteria yang harus dipenuhi adalah $\sum \mathrm{Wj}=1$, maka dari bobot sebelumnya akan diperbaiki berdasarkan rumus $w j=w j / \sum W j$, seperti dalam Tabel 3 .

Tabel 3. Keterangan Kriteria dan Bobot Kriteria

\begin{tabular}{|c|l|c|}
\hline KODE & \multicolumn{1}{|c|}{ NAMA KRITERIA } & BOBOT \\
\hline C01 & Jumlah Penghasilan & 0.18 \\
\hline C02 & Jumlah tanggungan & 0.13 \\
\hline C03 & Tempat Tinggal Orang Tua & 0.05 \\
\hline C04 & Nilai Rata-rata Semester & 0.13 \\
\hline C05 & Prestasi Non Akademis & 0.15 \\
\hline C06 & Memilikikartu KIP & 0.12 \\
\hline
\end{tabular}




\begin{tabular}{|l|l|c|}
\hline C07 & Memilikikartu PKH & 0.12 \\
\hline C08 & Memilikikartu KKS & 0.12 \\
\hline
\end{tabular}

\subsection{Nilai Alternatif}

Dari alternatif diaplikasikan untuk menetapkan penilaian pada altrnatif disetiap kriteria. Agar mempermudah penjelasan biasanya disajikan dalam bentuk tabel dimana alternatif ditempatkan di judul baris, dan kriteria ditempatkan di judul kolom. Setiap alternatif harus memiliki ini pada semua Kriteria meskipun hasilnya adalah 0 (nol).

Setelah pemberian bobot pada tiap-tiap kriteria, langkah selanjutnya adalah pembuatan matriks alternatif dan kriteria. Alternatif dalam penelitian ini menggunakan data calon penerima beasiswa yang sudah masuk pada SMK TR SINAR HUSNI Helvetia Medan, sedangkan nilai pada matriks alternatif dan kriteria ini didapat dari hasil wawancara dengan panitia penerima beasiswa. Dalam perhitungan ini di contohkan 5 alternatif calon penerima beasiswa dengan nilai perkriterianya seperti terlihat pada matrik keputusan tabel 4. Pada matriks keputusan, kolom matriks menyatakan atribut yaitu kriteria-kriteria yang ada, sedangkan baris matriks menyatakan alternatif yaitu calon penerima beasiswa beserta nilai kriterianya. Matriks keputusan mengacu terhadap $\mathrm{m}$ alternatif yang akan dievaluasi berdasarkan $\mathrm{n}$ kriteria.

Berikutcontoh Matriks alternative:

Tabel 4. Matrik Alternatif dan Kriteria

\begin{tabular}{|l|c|c|c|c|c|c|c|c|}
\hline & $\mathrm{C} 01$ & $\mathrm{C} 02$ & $\mathrm{C} 03$ & $\mathrm{C} 04$ & $\mathrm{C} 05$ & $\mathrm{C} 06$ & $\mathrm{C} 07$ & $\mathrm{C} 08$ \\
\hline Alwi Sihab & 2 & 3 & 1 & 3 & 5 & 5 & 5 & 5 \\
\hline Fanny Irvansyah & 5 & 1 & 1 & 3 & 1 & 5 & 5 & 5 \\
\hline Ilman Riki Maulana & 5 & 3 & 2 & 2 & 4 & 5 & 5 & 5 \\
\hline Ihsan Prandika & 3 & 3 & 4 & 4 & 1 & 5 & 5 & 5 \\
\hline Ahmad Fauzan & 5 & 3 & 2 & 4 & 2 & 5 & 5 & 5 \\
\hline
\end{tabular}

Tahap berikutnya adalah membangun matriks keputusan normalisasi(normalized decision matrix) yang elemennya ditentukan berdasarkan data pada tabel 4 . hasil dari normalisasi adapun nilainya dapat diketahui di tabel 5 .

Tabel 5. Matriks Ternormalisasi

\begin{tabular}{|l|c|c|c|c|c|c|c|c|}
\hline & $\mathrm{C} 01$ & $\mathrm{C} 02$ & $\mathrm{C} 03$ & $\mathrm{C} 04$ & $\mathrm{C} 05$ & $\mathrm{C} 06$ & $\mathrm{C} 07$ & $\mathrm{C} 08$ \\
\hline Alwi Sihab & 0.4264 & 1.4796 & 0,1961 & 1,2247 & 3,6466 & 2,2181 & 2,2181 & 2,2181 \\
\hline $\begin{array}{l}\text { Fanny } \\
\text { Irvansyah }\end{array}$ & 2.6650 & 0.1644 & 0,1961 & 1,2247 & 0,1458 & 2.6650 & 2.6650 & 2.6650 \\
\hline $\begin{array}{l}\text { Ilman Riki } \\
\text { Maulana }\end{array}$ & 2.6650 & 1.4796 & 0,7844 & 0,5443 & 2,3338 & 2.6650 & 2.6650 & 2.6650 \\
\hline Ihsan & 0.9594 & 1.4796 & 3,1378 & 2,1773 & 0,1458 & 2.6650 & 2.6650 & 2.6650 \\
\hline
\end{tabular}




\begin{tabular}{|l|l|l|l|l|l|l|l|l|}
\hline Prandika & & & & & & & & \\
\hline $\begin{array}{l}\text { Ahmad } \\
\text { Fauzan }\end{array}$ & 2.6650 & 1.4796 & 0,7844 & 2,1773 & 0,5834 & 2.6650 & 2.6650 & 2.6650 \\
\hline
\end{tabular}

Setelah matriks keputusan yang ternormalisasi terbentuk adalah membuat matriks hasil normalisasi terbobot (wndcm). Matriks ini didapat dengan mengalikan setiap baris pada matriks keputusan normalisasi (tabel 5) dengan bobot masing-masing kriteria $(\mathrm{Wj})$ seperti terlihat pada tabel 3, maka akan menghasilkan matrik ternormalisasi terbobot seperti terlihat pada tabel 6. Matrik keputusan normalisasi terbobot akan menentukan solusi ideal positif (A+) dan solusi ideal negatif (A-). Solusi ideal positif $(\mathrm{A}+)$ diperoleh dari nilai terbesar dari tiap kolom kriteria dan solusi ideal negatif (A-).

Tabel 6. Matriks Keputusan Ternormalisasi Terbobot

\begin{tabular}{|c|c|c|c|c|c|c|c|c|}
\hline & C01 & C02 & C03 & C04 & C05 & C06 & C07 & C08 \\
\hline $\begin{array}{c}\text { Alwi } \\
\text { Sihab }\end{array}$ & 0.1193 & 0.4142 & $\begin{array}{c}0.009 \\
8\end{array}$ & 0.2081 & 0.8022 & 0.8022 & 0.8022 & 0.8022 \\
\hline $\begin{array}{c}\text { Fanny } \\
\begin{array}{c}\text { Irvansy } \\
\text { ah }\end{array}\end{array}$ & 0.7462 & 0.0460 & $\begin{array}{c}0.009 \\
8\end{array}$ & 0.2081 & 0.0320 & 0.7462 & 0.7462 & 0.7462 \\
\hline $\begin{array}{c}\text { Ilman } \\
\text { Riki } \\
\text { Maulan } \\
\text { a }\end{array}$ & 0.7462 & 0.4142 & $\begin{array}{c}0.039 \\
2\end{array}$ & 0.0925 & 0.5134 & 0.7462 & 0.7462 & 0.7462 \\
\hline $\begin{array}{c}\text { Ihsan } \\
\text { Prandik } \\
\text { a }\end{array}$ & 0.2686 & 0.4142 & $\begin{array}{c}0.156 \\
8\end{array}$ & 0.3701 & 0.0320 & 0.7462 & 0.7462 & 0.7462 \\
\hline $\begin{array}{c}\text { Ahmad } \\
\text { Fauzan }\end{array}$ & 0.7462 & 0.4142 & $\begin{array}{c}0.039 \\
2\end{array}$ & 0.3701 & 0.1283 & 0.7462 & 0.7462 & 0.7462 \\
\hline $\mathbf{A}^{+}$ & $\mathbf{0 . 7 4 6 2}$ & $\mathbf{0 . 4 1 4 2}$ & $\mathbf{0 . 1 5 6}$ & $\mathbf{0 . 3 7 0 1}$ & $\mathbf{0 . 8 0 2 2}$ & $\mathbf{0 . 8 0 2 2}$ & $\mathbf{0 . 8 0 2 2}$ & $\mathbf{0 . 8 0 2 2}$ \\
\hline $\mathbf{A}^{-}$ & $\mathbf{0 . 1 1 9 3}$ & $\mathbf{0 . 0 4 6 0}$ & $\mathbf{0 . 0 0 9}$ & $\mathbf{0 . 0 9 2 5}$ & $\mathbf{0 . 0 3 2 0}$ & $\mathbf{0 . 7 4 6 2}$ & $\mathbf{0 . 7 4 6 2}$ & $\mathbf{0 . 7 4 6 2}$ \\
\hline
\end{tabular}

Tahap selanjutnya adalah menghitung separation measure yang merupakan pengukuran jarak dari alternatef ke solusi ideal positif (A+). Untuk menghitung separation measure ideal positif (S+) yaitu dengan mengurangi nilai matriks keputusan ternormalisasi terbobot dengan nilai solusi ideal positif (A+) lalu di kuadratkan yang hasilnya bisa terlihat pada tabel 7.Sedangkan menentukan separation measure untuk pengukuran jarak dari alternatif ke solusi ideal negatif (A-) yaitu dengan mengurangi nilai matriks keputusan ternormalisasi terbobot dengan nilai solusi ideal negatif (A-) dan di kuadratkan yang hasilnya dapat terlihat pada tabel 8 . 
Tabel 7. Matriks Keputusan Ternormalisasi Terbobot solusi Ideal Positif (A+)

\begin{tabular}{|l|c|c|c|c|c|c|c|c|}
\hline & $\mathrm{C} 01$ & $\mathrm{C} 02$ & $\mathrm{C} 03$ & $\mathrm{C} 04$ & $\mathrm{C} 05$ & $\mathrm{C} 06$ & $\mathrm{C} 07$ & $\mathrm{C} 08$ \\
\hline $\begin{array}{l}\text { Alwi } \\
\text { Sihab }\end{array}$ & 0.3930 & 0.0000 & $\begin{array}{c}0.021 \\
6\end{array}$ & 0.0262 & 0.0000 & 0.3239 & 0.3239 & 0.3239 \\
\hline $\begin{array}{c}\text { Fanny } \\
\text { Irvansy } \\
\text { ah }\end{array}$ & 0.0000 & 0.1355 & $\begin{array}{c}0.021 \\
6\end{array}$ & 0.0262 & 0.5932 & 0.388 & 0.388 & 0.388 \\
\hline $\begin{array}{c}\text { Ilman } \\
\text { Riki } \\
\text { Maulan } \\
\text { a }\end{array}$ & 0.0000 & 0.0000 & $\begin{array}{c}0.013 \\
8\end{array}$ & 0.0770 & 0.0834 & 0.0822 & 0.0822 & 0.0822 \\
\hline $\begin{array}{c}\text { Ihsan } \\
\text { Prandik } \\
\text { a }\end{array}$ & 0.2281 & 0.0000 & 0.000 & 0.0000 & 0.5932 & 0.4321 & 0.4321 & 0.4321 \\
\hline $\begin{array}{c}\text { Ahmad } \\
\text { Fauzan }\end{array}$ & 0.0000 & 0.0000 & 0.013 & 0.0000 & 0.4541 & 0.0000 & 0.0000 & 0.0000 \\
\hline
\end{tabular}

Tabel 8. Matriks Keputusan Ternormalisasi Terbobot solusi Ideal Negatif (A-)

\begin{tabular}{|c|c|c|c|c|c|c|c|c|}
\hline & $\mathrm{C} 01$ & $\mathrm{C} 02$ & $\mathrm{C} 03$ & $\mathrm{C} 04$ & $\mathrm{C} 05$ & $\mathrm{C} 06$ & $\mathrm{C} 07$ & $\mathrm{C} 08$ \\
\hline Alwi Sihab & $\begin{array}{c}0.00 \\
00\end{array}$ & 0.1355 & 0.0000 & 0.0133 & 0.5932 & 0.6829 & 0.6829 & 0.6829 \\
\hline $\begin{array}{c}\text { Fanny } \\
\text { Irvansyah }\end{array}$ & $\begin{array}{c}0.39 \\
30\end{array}$ & 0.0000 & 0.0000 & 0.0133 & 0.0000 & 0.7562 & 0.7562 & 0.7562 \\
\hline $\begin{array}{c}\text { Ilman Riki } \\
\text { Maulana }\end{array}$ & $\begin{array}{c}0.39 \\
30\end{array}$ & 0.1355 & 0.0008 & 0.0000 & 0.2317 & 0.7924 & 0.7924 & 0.7924 \\
\hline $\begin{array}{c}\text { Ihsan } \\
\text { Prandika }\end{array}$ & $\begin{array}{c}0.02 \\
22\end{array}$ & 0.1355 & 0.0216 & 0.0770 & 0.0000 & 0.6537 & 0.6537 & 0.6537 \\
\hline $\begin{array}{c}\text { Ahmad } \\
\text { Fauzan }\end{array}$ & 0.39 & 0.1355 & 0.0008 & 0.0770 & 0.0092 & 0.7142 & 0.7142 & 0.7142 \\
\hline
\end{tabular}

Hasil penghitungan pada tabel 7 kemudian dijumlahkan tiap barisnya, hasil dari penjumlahan itu kemudian diakarkuwadratkan untuk menghasilkan separation measure ideal positif (S+). Sedangkan untuk menghasilkan separation measure ideal negatif (S-) dilakukan dengan cara yang sama hanya saja data yang digunakan adalah tabel 8. Hasil perhitungan separation measure ideal positif dan separation measure ideal negatif digunakan untuk menentukan nilai preferensi setiap alternatif $(\mathrm{Ci})$. Nilai preferensi di peroleh dengan cara membagi nilai separation measure ideal negatif (S-) dengan jumlah dari separation measure ideal positif (S+) dan separation measure ideal negatif (S-). Nilai preferensi setiap alternatif digunakan untuk menentukan ranking tiap-tiap alternatif seperti terlihat pada Tabel 9. 
Tabel 9. Rangking

\begin{tabular}{|l|c|c|c|c|}
\hline \multicolumn{1}{|c|}{ Alternatif } & $\mathbf{S}^{+}$ & $\mathbf{S}^{-}$ & Nilai & Rangking \\
\hline Alwi Sihab & 1.2838 & 1.6705 & 0.5654 & 3 \\
\hline Fanny Irvansyah & 1.3930 & 1.6355 & 0.5400 & 4 \\
\hline $\begin{array}{c}\text { Ilman Riki } \\
\text { Maulana }\end{array}$ & 0.6486 & 1.7726 & 0.7321 & 1 \\
\hline Ihsan Prandika & 1.4756 & 1.4890 & 0.5022 & 5 \\
\hline Ahmad Fauzan & 0.6840 & 1.6607 & 0.7085 & 2 \\
\hline
\end{tabular}

Dari hasil diatas dapat diketahui bahwa Ilman Riki Maulana memiliki nilai 0.7321 tertinggi dan ia menjadi prioritas untuk mendapatkan beasiswa disusul peringkat 2, Ahmad Fauzan memiliki nilai 1.6607, di peringkat ke 3 ada Alwi Sihab dengan nilai 0.5654, peringkat 4, Fanny Irvansyah memiliki nilai 0.5400 , dan yang terakhir Ihsan Prandika dengan nilai 0.5022 , dari perhitungan diatas dapat diketetahui bahwa yang paling berhak mendapatka rekomendasi beasiswa di SMK sinar husni adalah Ilman Riki Maulana dengan nilai 0.7321

\section{KESIMPULAN}

Dari hasil penelitian yang telah dijabarkan diatas maka dapatlah diambil kesimpulan antara lain :

1. Perhitungan manual metode TOPSIS perhitungan sama dengan program.

2. menggunakan metode TOPSIS dengan 8 (delapan) kriteria yang digunakan yaitu Jumlah penghasilan orang tua, Jumlah Tanggungan Orang Tua, Tempat tinggal orang tua, Nilai ratarata semester, Prestasi non akademis,Memiliki Kartu KIP, Memiliki Kartu PKH,Memiliki Kartu KKS.

3. Alternatif yang dijadikan sampel pada peneliti ini adalah data calon seleksi penerimaan beasiswa yang sudah masuk di SMK TR SINAR HUSNI Helvetia Medan.

4. Berdasarkan hasil perhitungan yang sesuai dengan tahapan-tahapan dalam metode TOPSIS diperoleh perankingan terhadap calon penerima beasiswa dengan posisi pertama Ilman Riki Maulana mendapatkan nilai 0.7321, posisi kedua Ahmad Fauzan mendapatkan nilai 0.7085, posisi ketiga Alwi Sihab dengan nilai 0.5654 , posisi ke empat Fanny Irvansyah dengan nilai 0.5400 , dan posisi kelima Ihsan Prandika dengan nilai 0.5022

\section{SARAN}

Ada beberapa saran yang diusulkan yaitu :

1. Diharapkan dalam penelitian berikutnya lebih di tambah lagi kriteria untuk beasiswa yang akan menjadi bagian perhitungannya.

2. Dalam penelitan berikutnya perlujuga di tambah dengan metode-metode lain sebagai metode pelengkap. 


\section{DAFTAR PUSTAKA}

[1] Widayanti, T., \& Wijaya, T. (2016). Implementasi Metode TOPSIS dalam Sistem Pendukung Keputusan Seleksi Penerima Beasiswa Bidikmisi Berbasis Web. Creative Information Technology Journal, 3(4), 344-355

[2] Arifah, D. (2013). Analisa dan Perancangan Sistem Pendukung Keputusan Pemilihan Kendaraan Menggunakan Metode TOPSIS. Jurnal Teknologi Informasi, 5(1), 41-42.

[3] Setiawan, A. (2019). PENGAMBILAN KEPUTUSAN UNTUK MENYELEKSI PENERIMAAN GURU MATEMATIKA DENGAN METHODE TOPSIS. METHOMIKA: Jurnal Manajemen Informatika \& Komputerisasi Akuntansi, 3(1), 14-20

[4] Muzakkir, I. (2017). Penerapan metode topsis untuk sistem pendukung keputusan penentuan keluarga miskin pada desa panca karsa ii. ILKOM Jurnal Ilmiah, 9(3), 274-281.

[5] HASIBUAN, Z. (2013). SISTEM PENDUKUNG KEPUTUSAN PENENTUAN CALON PENERIMA BEASISWA SEKOLAH GRATIS MENGGUNAKAN METODE FCM DAN TOPSIS (Studi Kasus: Sekolah Dasar Juara Pekanbaru) (Doctoral dissertation, UNIVERSITAS ISLAM NEGERI SULTAN SYARIEF KASIM RIAU)

[6] Apau, R., \& Adomako, C. (2017). Design of Image Steganography based on RSA Algorithm and LSB Insertion for Android Smartphones. International Journal of Computer Applications, 164(1), 0975-8887.

[7] Ma'ruf, M. R. (2016). Pengembangan Sistem Pendukung Keputusan Pemilihan Supplier Menggunakan Metode Topsis Pada Perusahaan Furniture.

[8] Setiawan, A., \& Darma, S. (2013). Implementasi Decision Support System Dalam Penseleksian Calon Anggota Baru Badan Eksekutif Mahasiswa (BEM) dengan Metode GAP Kompetensi (Studi Kasus: Universitas Potensi Utama). SEMNASTEKNOMEDIA ONLINE, 3(1), 2-2.

[9] Chamid, A. A. (2016). Penerapan Metode Topsis Untuk Menentukan Prioritas Kondisi Rumah. Simetris: Jurnal Teknik Mesin, Elektro dan Ilmu Komputer, 7(2), 537-54.

[10] Noranda, O., Ariyanto, R., \& Ririd, A. R. T. H. (2016, November). SISTEM PENDUKUNG KEPUTUSAN PEMBERIAN ZAKAT PENDIDIKAN DI BAITUL MAAL HIDAYATULLAH KOTA MALANG. In Seminar Informatika Aplikatif Polinema

[11] Suyatmo, S., Aris Rakhmadi, S. T., \& Eng, M. (2017). Sistem Pendukung Keputusan Menentukan Lokasi Tanam Tanaman Holtikultura (Sayuran) Menggunakan Metode Topsis (Doctoral dissertation, Universitas Muhammadiyah Surakarta).

[12] Marsono, W. D., \& Boy, A. F. (2015). Sistem Pendukung Keputusan Pemilihan Menu Makanan pada Penderita Obesitas dengan menggunakan Metode TOPSIS. Jurnal SAINTIKOM, 14. 